\title{
Glycogen Synthase Kinase-3 regulates multiple myeloma cell growth and bortezomib-induced cell death
}

Francesco Piazza ${ }^{1,2}$, Sabrina Manni ${ }^{1,2}$, Laura Quotti Tubi ${ }^{1,2}$, Barbara Montini ${ }^{1,2}$, Laura Pavan ${ }^{1,2}$, Anna Colpo ${ }^{1,2}$, Marianna Gnoato ${ }^{1,2}$, Anna Cabrelle ${ }^{1,2}$, Fausto Adami ${ }^{1}$, Renato Zambello ${ }^{1,2}$, Livio Trentin ${ }^{1,2}$, Carmela Gurrieri ${ }^{1,2}$, Gianpietro Semenzato ${ }^{1,2^{*}}$

\begin{abstract}
Background: Glycogen Synthase Kinase-3 (GSK-3) $\alpha$ and $\beta$ are two serine-threonine kinases controlling insulin, Wnt $/ \beta$-catenin, NF- $\kappa \mathrm{B}$ signaling and other cancer-associated transduction pathways. Recent evidence suggests that GSK-3 could function as growth-promoting kinases, especially in malignant cells. In this study, we have investigated GSK-3 $\alpha$ and GSK-3 $\beta$ function in multiple myeloma (MM).

Methods: GSK-3 $\alpha$ and $\beta$ expression and cellular localization were investigated by Western blot (WB) and immunofluorescence analysis in a panel of MM cell lines and in freshly isolated plasma cells from patients. MM cell growth, viability and sensitivity to bortezomib was assessed upon treatment with GSK-3 specific inhibitors or transfection with siRNAs against GSK-3 $\alpha$ and $\beta$ isoforms. Survival signaling pathways were studied with WB analysis.

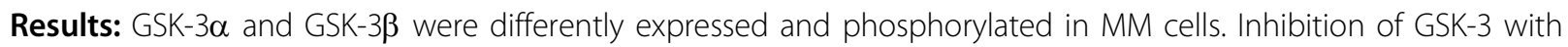
the ATP-competitive, small chemical compounds SB216763 and SB415286 caused MM cell growth arrest and apoptosis through the activation of the intrinsic pathway. Importantly, the two inhibitors augmented the bortezomib-induced MM cell cytotoxicity. RNA interference experiments showed that the two GSK-3 isoforms have distinct roles: GSK-3 $\beta$ knock down decreased MM cell viability, while GSK-3 $\alpha$ knock down was associated with a higher rate of bortezomib-induced cytotoxicity. GSK-3 inhibition caused accumulation of $\beta$-catenin and nuclear phospho-ERK1, 2. Moreover, GSK-3 inhibition and GSK-3 $\alpha$ knockdown enhanced bortezomib-induced AKT and MCL-1 protein degradation. Interestingly, bortezomib caused a reduction of GSK-3 serine phosphorylation and its nuclear accumulation with a mechanism that resulted partly dependent on GSK-3 itself.
\end{abstract}

Conclusions: These data suggest that in MM cells GSK-3 $\alpha$ and $\beta$ i) play distinct roles in cell survival and ii) modulate the sensitivity to proteasome inhibitors.

\section{Background}

GSK-3 is a pleiotropic serine-threonine kinase discovered for its involvement in insulin signaling. Two major isozymes (GSK-3 $\alpha$ and GSK-3 $\beta$ ) are known and conserved throughout the species [1]. This kinase is involved in cell proliferation and survival by controlling the $\mathrm{Wnt} / \beta$-catenin and growth factors (GFs)-dependent pathways [2].

\footnotetext{
* Correspondence: g.semenzato@unipd.it

'Department of Clinical and Experimental Medicine, Hematology and Clinical Immunology Branch, University of Padua School of Medicine, Via Giustiniani 2 -35128-Padua, Italy

Full list of author information is available at the end of the article
}

Constitutive GSK-3-mediated phosphorylation directs $\beta$-catenin to proteasome-mediated degradation [3]. Upon activation of Wnt signalling, GSK-3 activity is hampered and unphosphorylated $\beta$-catenin accumulates in the cytosol, translocates to the nucleus and promotes gene transcription and cell growth by acting as a co-activator of the transcription factors TCF/LEF $[3,4]$. GSK-3 is also inhibited by the action of the Phosphatidylinositol 3-OH kinase (PI3K)/AKT cell-survival pathway through phosphorylation on serine 21 (GSK-3 $\alpha$ ) and serine 9 (GSK-3 $\beta$ ) [2]. Since Wnt/ $\beta$-catenin and PI3K/AKT-dependent signaling 
pathways promote cell growth, GSK-3 has been considered a growth-suppressor. By contrast, GSK-3 $\beta$ has been found essential for cell survival by critically regulating NF$\kappa \mathrm{B}$ transcription factor activity and by protecting cells from TNFa [5] and TRAIL-induced apoptosis [6-9]. Moreover, while a number of studies demonstrated that GSK-3 may favor intrinsic apoptosis [10-12], other work showed that its inhibition could result in cancer cell apoptosis and growth arrest, in some cases due to an impaired NF- $\kappa$ B activity [8,13-15]. Taken together, several lines of evidence indicate that GSK-3 could play a twofold role in cell survival, depending on the different contexts (for instance, malignant versus non-malignant cells) or on whether apoptosis is started by intrinsic or extrinsic mechanisms [16]. However, a caveat for many of these studies is that GSK-3 $\alpha$ and $\beta$ isoforms were not evaluated separately.

Multiple myeloma (MM) is an incurable malignancy of plasma cells $(\mathrm{PC})$ that clonally expand in the bone marrow (BM) [17]. Signaling pathways that might lead to GSK-3 inactivation and to NF- $\kappa \mathrm{B}$ activation have been implicated in MM pathogenesis [18,19]. For instance, interleukin-6 (IL-6) production by BM stromal cells (BMSC), which stimulates malignant $\mathrm{PC}$ growth and expression of adhesion molecules, is NF- $\kappa \mathrm{B}$-dependent [20]. Insulin-like Growth Factor-I (IGF-I), an important growth and chemotactic factor for MM cells [21,22], can activate both PI3K/AKT and NF- $\kappa \mathrm{B}$. Also, Tumor Necrosis Factor- $\alpha$ (TNF $\alpha$ ) produced in the tumor microenvironment can lend MM cells the ability to escape apoptosis by up regulating NF- $\kappa \mathrm{B}$ dependent anti-apoptotic molecules [23]. Whether GSK-3 plays a role in NF- $\kappa$ B activation in MM and other blood tumors upon these and other stimuli is largely unknown. Moreover, the Wnt/ $\beta$ catenin pathway causes MM cells proliferation [24], suggesting that secreted Wnt proteins in the BM microenvironment may act as GFs for malignant plasma cells. Furthermore, active Wnt signaling is also crucially involved in osteoblast differentiation $[25,26]$. Interestingly, the Wnt antagonist DKK1 is over expressed in MM patients displaying impaired bone formation and bone lytic lesions [27]. In this scenario, GSK-3, by inhibiting Wnt signaling, should be a growth brake for MM cells but also a negative regulator of osteoblastogenesis. Thus, the use of GSK-3 inhibitors to by-pass the DKK1mediated Wnt signaling block on osteoblast precursors that has been proposed with the aim to slow down the progression of myeloma bone disease $[28,29]$ - could be hazardous. It is hence important to study both the role of GSK-3 in MM cell growth as well as the effects of its inhibition on the MM cell-tumor microenvironment interactions. Likewise, the investigation of the potential regulation of drug-induced cytotoxicity by GSK-3 expected to occur in light of its role in the NF- $\kappa \mathrm{B}$ signaling - would provide hints to determine the feasibility of this potentially useful therapeutic approach in MM therapy.

With this as a background, the aim of our study was to analyze GSK-3 role in MM cell growth and survival. By using selective ATP-competitive small chemical GSK-3 inhibitors as well as gene knock down by RNA interference, we investigated the consequences of GSK-3 ( $\alpha$ and $\beta$ ) down regulation in MM cells. We found that treatment of MM cells with GSK-3 inhibitors and GSK$3 \beta$ knock down caused growth arrest and apoptosis by perturbing pivotal signaling pathways. We also found that the GSK-3 inhibitors and GSK-3 $\alpha$ knock down enhanced the anti-MM cytotoxic effect of bortezomib, a clinically used proteasome inhibitor.

\section{Results}

\section{GSK-3 expression in MM cells}

GSK-3 $\alpha / \beta$ (hereafter referred as GSK-3) activity is mainly inhibited through AKT [30] or S6K1 kinasedependent [31] phosphorylation on Ser 9 (GSK-3 $\beta$ ) and $21(\mathrm{GSK}-3 \alpha)$. Since MM cells receive signals that activate these two kinases, we investigated the expression of total and serine-phosphorylated (inactive) GSK-3 in these cells. Protein lysates were obtained from PBMC of 4 healthy subjects, normal in vitro generated PC (nPC), 9 primary $\mathrm{MM}$ samples $\left(\mathrm{CD} 138^{+}\right.$malignant $\left.\mathrm{PC}\right), 4 \mathrm{MM}$ cell lines (MMCLs); immunoblot analysis of total and serine-phosphorylated GSK-3 was then performed. As shown in Fig. 1A, we noticed an abundant expression of total GSK-3 in PBMC and nPC, both of the $\alpha$ and of the $\beta$ isoform. In some MM cells from patients (namely cases 1, 2, 7 and 9) the GSK-3 $\beta$ isoform was moderately less expressed. This difference was seemingly more evident in the U-266, RPMI- 8226 and INA-6 cell lines.

\section{GSK-3 phosphorylation in MM cells}

We observed that the GSK-3 $\beta$ isoform resulted to be more phosphorylated on Ser 9 than GSK-3 $\alpha$ on Ser 21, both in normal and in malignant cells, suggesting that its catalytic activity is buffered down. Since GSK-3 tyrosine phosphorylation indicates its activation, to further confirm these results, we performed WB analysis of the levels of phopsho-Tyr 279 GSK-3 $\alpha$ and phospho-Tyr 216 GSK-3 $\beta$ on protein lysates of patients 7, 3 and 1 . As shown in Fig. 1B, primary MM cells from three patients displayed a prevailing tyrosine phosphrylation of GSK$3 \alpha$, whereas the levels of phospho-Tyr GSK-3 $\beta$ were barely detectable.

\section{GSK-3 subcellular localization in MM cells}

We next analyzed the intracellular localization of GSK-3 in malignant PC by confocal immunofluorescence (IF). In resting non-malignant cells GSK-3 localizes mostly in 


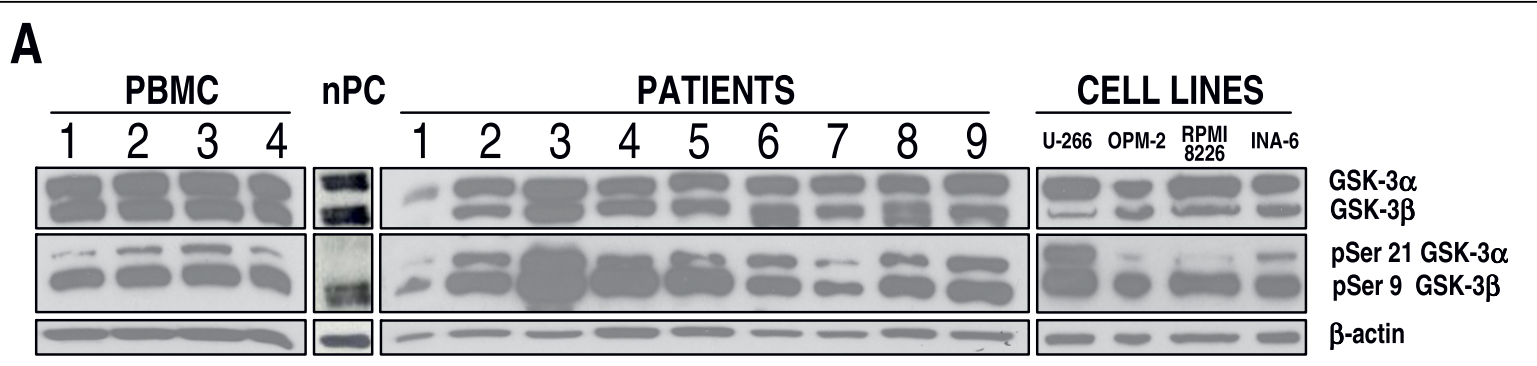

\section{B}

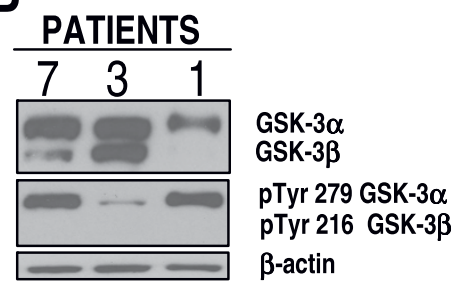

C

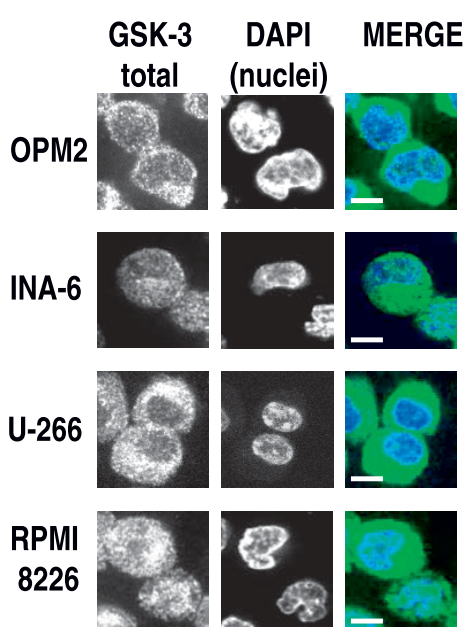

D

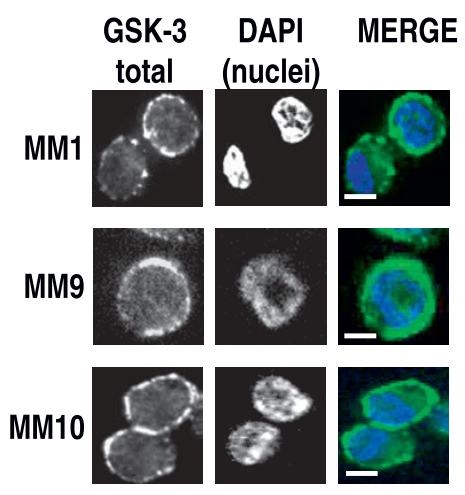

E

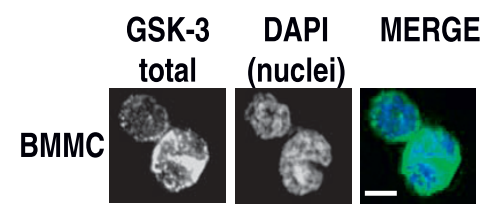

Figure 1 GSK-3 expression, phosphorylation and localization in MM cells. (A) WB for total GSK-3 $\alpha$ and $\beta$ (top panels), phosphorylated GSK-3 $\alpha$ (on Ser 21) and GSK-3 $\beta$ (on Ser 9) (middle panels), and $\beta$-actin as loading control (bottom panels) in (from left to right): 4 PBMC samples of healthy subjects, non-malignant in vitro-generated PC (nPC), CD138 $8^{+}$purified PC from 9 MM patients, 4 MMCLs; (B) WB for total GSK-3 $\alpha$ and $\beta$ (top panels), phosphorylated GSK-3 $\alpha$ (on Tyr 279) and GSK-3 $\beta$ (on Tyr 216) (middle panels) and $\beta$-actin as loading control (bottom panels), in three primary MM plasma cell samples (MM 7, 3, 1). (C-E): GSK-3 immunostaining and confocal microscopy analysis in MMCLs OPM-2, INA-6, U-266 and RPMI-8226 (C), three CD138+ primary malignant PC from patients (MM1, MM9, MM10) (D) and BMMC (E). In the merged images GSK-3 is detected by green fluorescence and nuclei are in blue. Scale bars $=10 \mu \mathrm{m}$. For all the images: $600 \times$ magnification, oil objective.

the cytoplasm and smaller pools of the kinase are present in the nucleus and other organelles where they exert specialized functions [32,33]. However, in some tumors, GSK-3 $\beta$ was found localized mostly in the nuclear compartment [14,34]. In MMCLs (OPM-2, INA-6, U-266 and RPMI-8226) GSK-3 was present in the cytosol (more in OPM-2 and U-266) and in the nucleus (more in INA-6 and RPMI-8226 cells); in primary malignant $\mathrm{PC}$ from 3 patients (indicated as MM1, MM9 and MM10) GSK-3 was found to be scarcely localized in the nucleus, much more in the cytosol and also close to the cell membrane (Fig. 1C and 1D); in control BMMC the intracellular distribution of GSK-3 was mostly cytosolic and/or with a speckled-like nuclear pattern and with very little presence at the plasma membrane edge (Fig. 1E).

Effects of GSK-3 inhibitors on GSK-3 activity in MM cells To investigate GSK-3 function in MM cells we used the well characterized in vitro and in vivo, ATP-competitive, 
GSK-3 chemical inhibitors SB216763 and SB415286. These compounds were tested in previous studies for their activity against a panel of several different kinases $(>20)$, displaying a fairly high specificity for GSK-3 $\alpha$ and GSK-3 $\beta[35,36]$. First, we tested the efficacy to inhibit GSK- 3 by culturing MM cells OPM- 2 and RPMI-8226 in the presence of the two compounds. These two cell lines were chosen since they displayed lower phosphoserine GSK-3 $\alpha / \beta$ levels (and thus higher activity) than the others. Total GSK- 3 activity ( $\alpha$ plus $\beta$ isozymes) was then determined on cellular protein lysates after 24 hours using a radioactive kinase assay. The inhibitory activity of SB216763 and SB415286 was assayed against

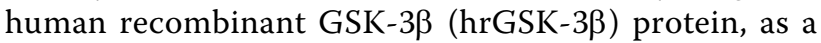
control. As shown in Fig. 2A (OPM-2 cell line) and Fig. 2B (RPMI-8226 cell line), both the inhibitors hampered hrGSK-3 $\beta$ (leftmost graph) and endogenous (rightmost graph) GSK-3 activity $(p<0.05, \mathrm{n}=3)$. Similar results were obtained using U-266 and INA-6 cells (not shown), demonstrating that these compounds can efficiently inhibit the active pool of GSK-3 in MM cells.

\section{GSK-3 down regulation decreases MM cell growth and survival}

We next checked the effects of the GSK-3 inhibitors on malignant PC growth by treating MM cells with increasing concentrations of SB415286 or SB216763. In these conditions, all the MMCLs tested displayed a dosedependent decrease of their growth as determined by reduced thymidine incorporation (U-266, INA-6) $(p<$ $0.05, \mathrm{n}=4$ ) (Fig. 2C) and BrdU staining (RPMI-8226, U-266, INA-6) $(p<0.05, \mathrm{n}=5)$ (data not shown), indicating that GSK-3 may function as a growth-promoter in these cell lines. Data were represented as percent of untreated cells (made equal to $100 \%$ of incorporation of ${ }^{3} \mathrm{H}$-thymidine evaluated as counts per minutes or $100 \%$ of BrdU fluorescence staining evaluated by FACS analysis, as specified in Methods).

Then, we investigated whether apoptosis could be one mechanism of growth inhibition in GSK-3 inhibitortreated MM cells. Annexin V staining and FACS analysis experiments using U-266, RPMI-8226 and INA-6 cells showed that treatment with SB415286 resulted in a moderate though significant reduction of cell viability $(p<0.05, \mathrm{n}=5)$ (Fig. 3A, graph on the left). Importantly, at this concentration of SB415286 normal PBMCs did not display apoptosis as compared to untreated samples (Fig. 3A, graph on the right). To further validate the above results, we measured the electrochemical gradient across the mitochondrial membrane in the absence or presence of GSK-3 inhibition (4 or $8 \mu \mathrm{M}$ SB415286). Experiments carried out with the JC-1 dye [37] showed that GSK-3 inhibition in INA-6 and U-266 cells caused the disruption of the mitochondrial membrane potential (increase of the number of cells stained with JC-1 green-fluorescent monomers, $p<0.01, \mathrm{n}=5$ ) (Fig. 3B). Furthermore, WB analysis of protein lysates obtained from SB216763-treated RPMI-8226 cells revealed that GSK-3 inhibition was associated with a significant reduction of the amount of phospho-Tyr 279 GSK-3 $\alpha$ and phospho-Tyr 216 GSK$3 \beta$, indicating that the compound efficiently inhibited the autocatalytic activity of GSK-3, in agreement with previous studies $[38,39]$ and with our above described in vitro kinase assays. To note, SB216763 caused activation of the intrinsic mitochondria-dependent apoptosis evidenced by Poly (ADP ribose) polymerase (PARP) cleavage and a significant increase of Smac/DIABLO cytoplasmic protein levels (Fig. 3C, top panels). Also SB415286-treatment of INA-6 cells caused apoptosis and PARP cleavage, time-dependently (Fig. 3C, bottom panels).

\section{Inhibition of GSK-3 increases $\beta$-catenin and phospho- ERK1, 2 levels in MM cells}

Next, we investigated the effects of SB216763 and SB415286 (not shown) treatment of U-266 MM cells on GSK-3-related signaling pathways by WB experiments using cytoplasmic and nuclear protein lysates (Fig. 3D). The GSK-3 inhibitors caused a significant increase of $\beta$-catenin levels, in the cytoplasm and in the nucleus, as expected - again showing a remarkable inhibition of GSK3 Tyr phosphorylation. Interestingly, in the presence of GSK-3 inhibition an accumulation of GSK-3 in the cytosol was observed. We also looked at the ERK1/2 pathway, an important proliferative cascade for MM cells, since GSK-3 was shown to negatively regulate it in the myocardial muscle [40] and in immune cells [41]. Indeed, ERK1/2 phosphorylation was also affected by GSK-3 inhibition - even if in a slighter fashion - with mild increase of the phosphoThr202/Tyr204 ERK1, 2 nuclear pool, indicating a role likely minor - for GSK-3 in this context (Fig. 3D).

\section{Molecular sequelae and effects of GSK-3 inhibition on bortezomib-dependent cytotoxicity in MM cells}

Since GSK-3 controls MM cell survival, we next checked whether it could modulate the pro-apoptotic effects of the proteasome inhibitor bortezomib (BZ), a clinically used anti-MM agent that down modulates growth-promoting pathways, triggers mitochondria-dependent apoptosis [42] and interferes with MM cell-BMSC interactions [43]. To this aim, MM cells (U-266 and RPMI-8226) were treated with either $4 \mu \mathrm{M}$ SB415286, either $5 \mathrm{nM}$ BZ or both and annexin $\mathrm{V}$ staining and FACS analysis were used to quantify apoptosis. As shown in Fig. 4A, the simultaneous treatment of MM cells (U-266 and RPMI-8226) with the GSK-3 inhibitor and BZ caused a moderate but significant increase of apoptosis in both MM cell lines as compared 


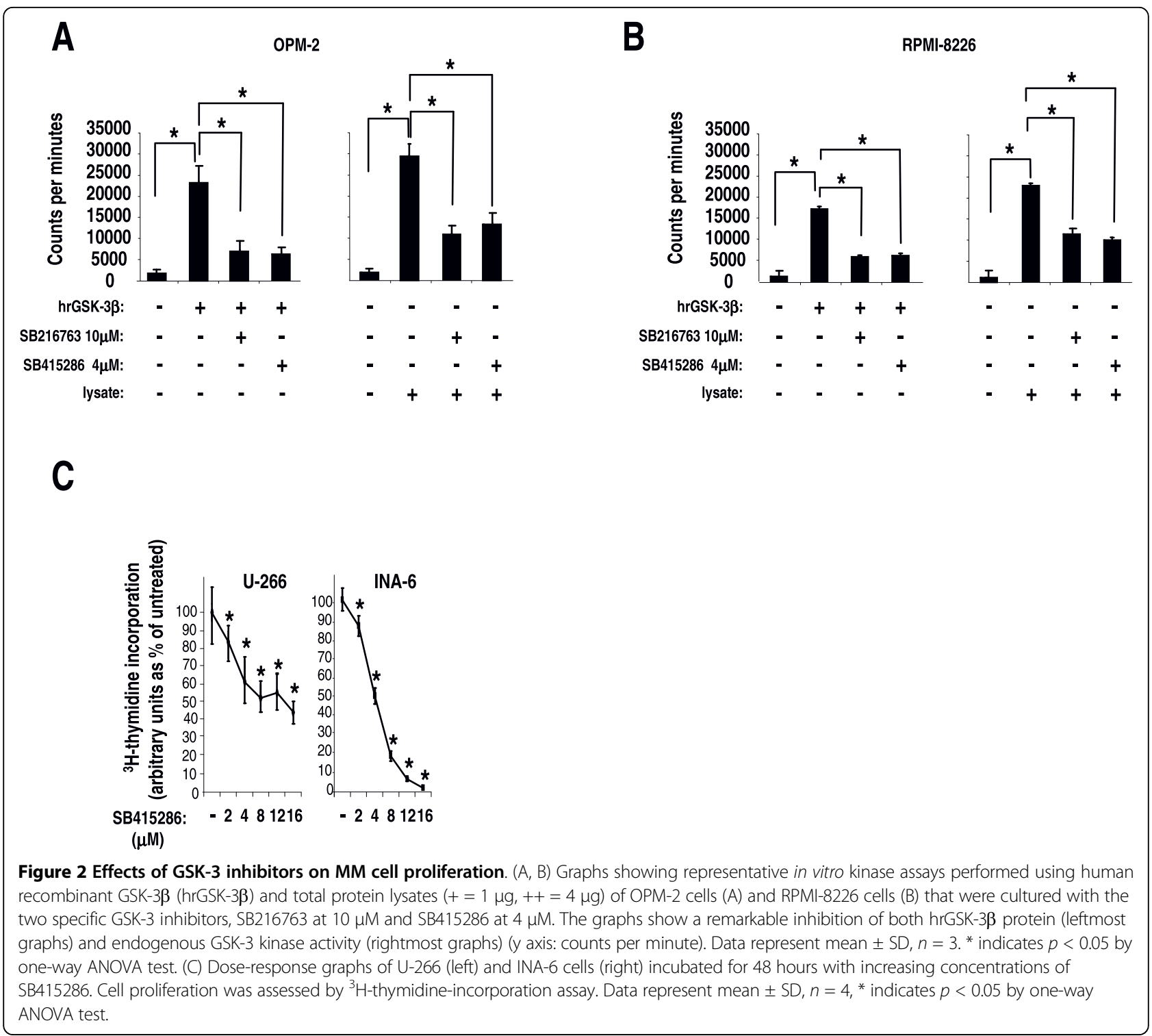

with the apoptotic rate observed with single treatments ( $p$ $<0.05, \mathrm{n}=3$ for both series of experiments). Immunoblot analysis of survival and BZ-regulated MM molecules confirmed that SB415286 caused an enhanced PARP cleavage in the nucleus compared to untreated samples. BZ exposure of MM cells was accompanied by a more pronounced PARP cleavage and, interestingly, by an increase of nuclear phospho-Ser 473 AKT levels, a reduction of total AKT and of the anti-apoptotic BCL-2 family member MCL-1 protein levels. These effects of $\mathrm{BZ}$ were already described in other studies [44,45], even though in certain cancer cell types BZ was shown to reduce phospho-Ser 473 AKT levels $[46,47]$. Remarkably, the treatment of MM cells with GSK-3 inhibitors together with BZ resulted in an even further increase of PARP cleavage and reduction of
phospho-Ser 473 AKT levels, total AKT and MCL-1 protein levels (Fig. 4B).

\section{GSK-3 $\alpha$ and $\beta$ silencing by RNA interference unveils a} different role for the two isoforms in MM cell survival To further analyze the role of GSK-3 in MM cell growth we performed RNA interference experiments to knock down GSK-3 $\alpha$ and GSK-3 $\beta$ protein expression levels in U-266 cells. As shown in Fig. 5A, we could achieve a significant reduction of GSK-3 $\alpha$ (left panel) and GSK-3 $\beta$ (right panel) protein levels, peaking 48 hours and lasting as long as 72 hours after U-266 MM cells nucleofection with specific GSK-3 $\alpha$ or GSK-3 $\beta$-directed small interfering RNA oligos. The efficiency of transfection was high (transfected cells ranged from $80 \%$ to $>90 \%$ ) in all the 


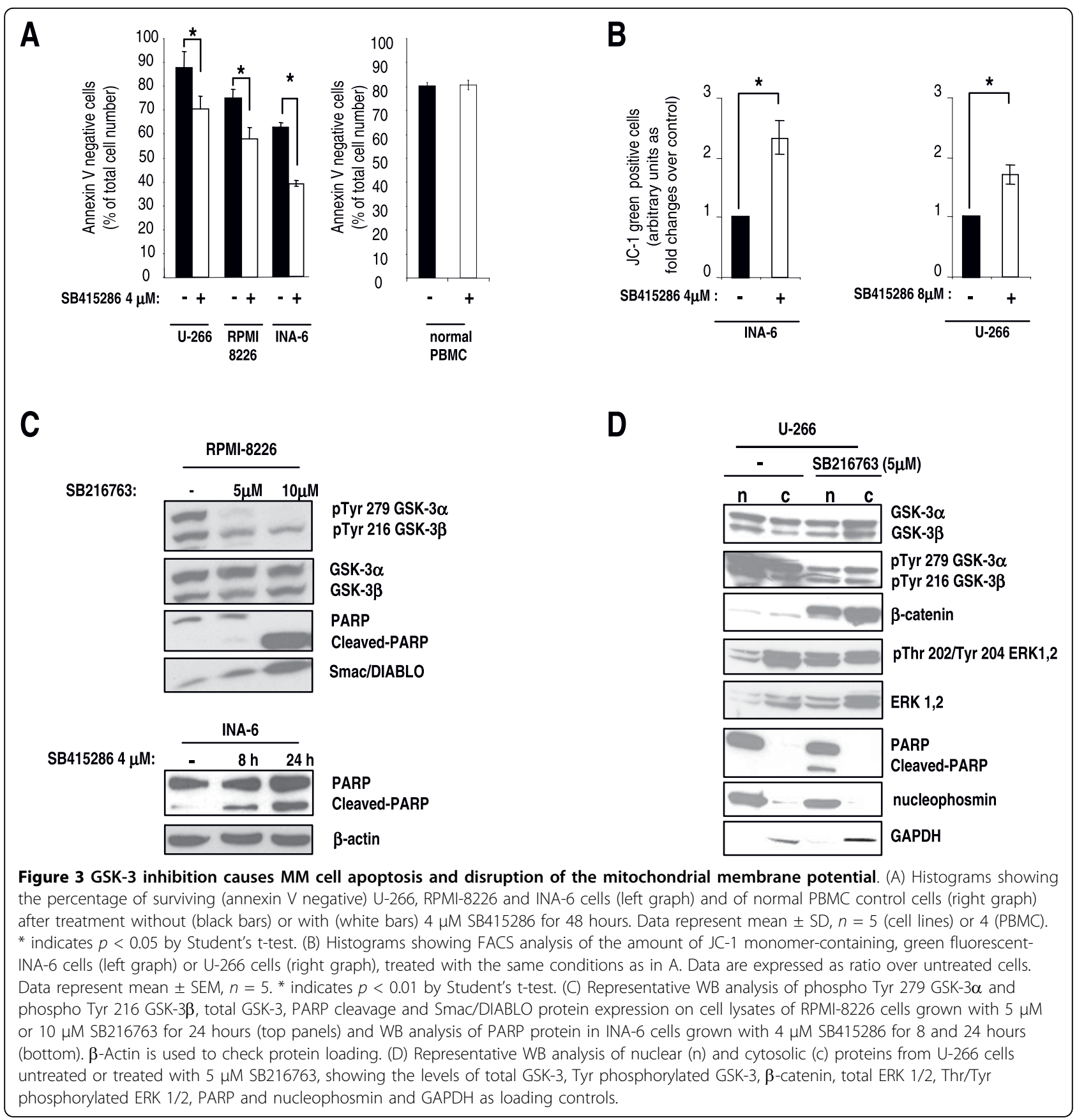

experiments performed (not shown). The control samples, either un-transfected or transfected with blank buffer or with scrambled RNA oligonucleotides did not show significant alterations of the protein kinase levels. Since as markers of nucleofection efficiency we used fluorescent RNA oligos that had an emission spectrum overlapping with those of propidium iodide, annexin $\mathrm{V}$ and JC-1, we used light microscopy as an alternative mean to analyze cell viability; this assay revealed that GSK-3 $\beta$-silenced cells were more irregularly-shaped with picnotic nuclei as compared to cells transfected with scrambled or GSK-3 $\alpha$-targeting siRNAs (Fig. 5B, left panels). Moreover, the quantitative analysis of cellular morphology and granularity by FACS showed that GSK$3 \beta$-silenced samples displayed approximately a 1.4 fold increase in the percentage of dying [low forward scatter (FSC)/high side scatter (SSC)] cells as compared to samples transfected with scrambled siRNAs $(p<0.05, \mathrm{n}=6)$. This effect was not evident when GSK-3 $\alpha$ was knocked down (Fig. 5B, middle panels; in the rightmost graphs 


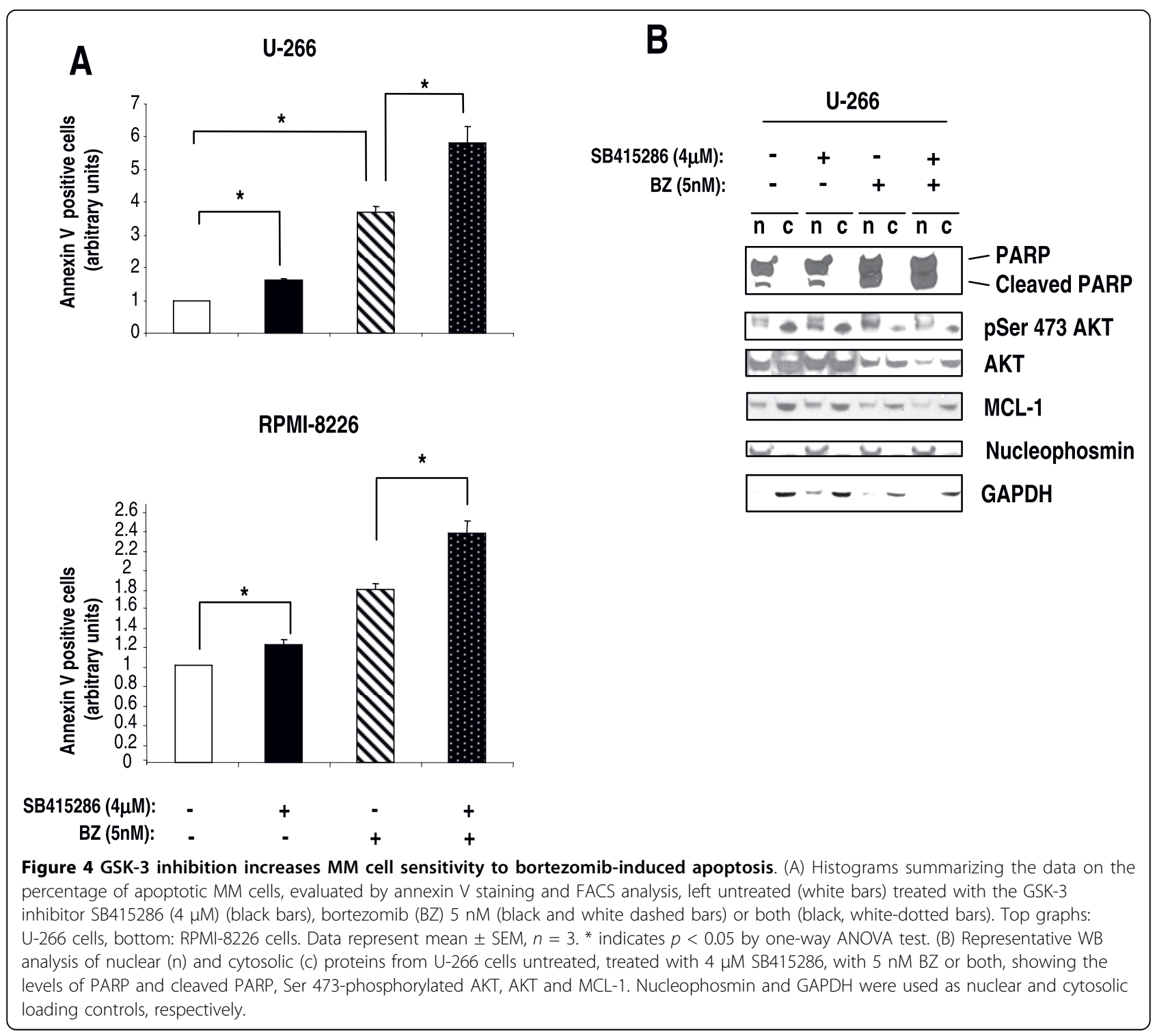

data are summarized in histogram plots). In addition, silencing of GSK3 $\alpha$ did not cause a substantial reduction of the unprocessed PARP protein as opposed to silencing of GSK-3 $\beta$, suggesting that, at basal growing conditions, only GSK-3 $\beta$ may partially sustain MM cell survival (Fig. 5C).

\section{GSK-3 $\alpha$ knock down empowers bortezomib-induced cell death}

To confirm the results obtained with BZ and GSK-3 inhibitors, we carried out RNA interference experiments of GSK- $3 \alpha$ and GSK-3 $\beta$ subunits in U-266 MM cells; 48 hours after transfection with the targeting siRNAs, cells were grown for additional 18 hours with or without BZ. Cells were then analyzed by light microscopy and FACS for morphological changes indicative of decreased viability, as above described. Treatment with BZ $5 \mathrm{nM}$ caused marked apoptosis. Interestingly, knock down of GSK- $3 \alpha$, but not of GSK-3 $\beta$, was associated with an increase of BZ-induced cell death, as evidenced by more irregularly-shaped cells with picnotic nuclei by light microscopy (Fig. 5D, left panels). Moreover, we did not observe significant changes in the percentage of lowFSC/high-SSC cells by FACS analysis of GSK- $3 \beta$ silenced and BZ-treated cells (Fig. 5D, right panels, bottom graph), whereas we could detect a statistically significant decrease of viability in the GSK-3 $\alpha$-silenced and BZ-treated samples $(p<0.05, \mathrm{n}=3)$ as compared to scrambled oligos-transfected controls (Fig. 5D, right panels, top graph). We next analyzed U-266 cell viability upon silencing of both the GSK-3 isoforms and BZ treatment. As shown in the graph in Fig. 5E, RNA 


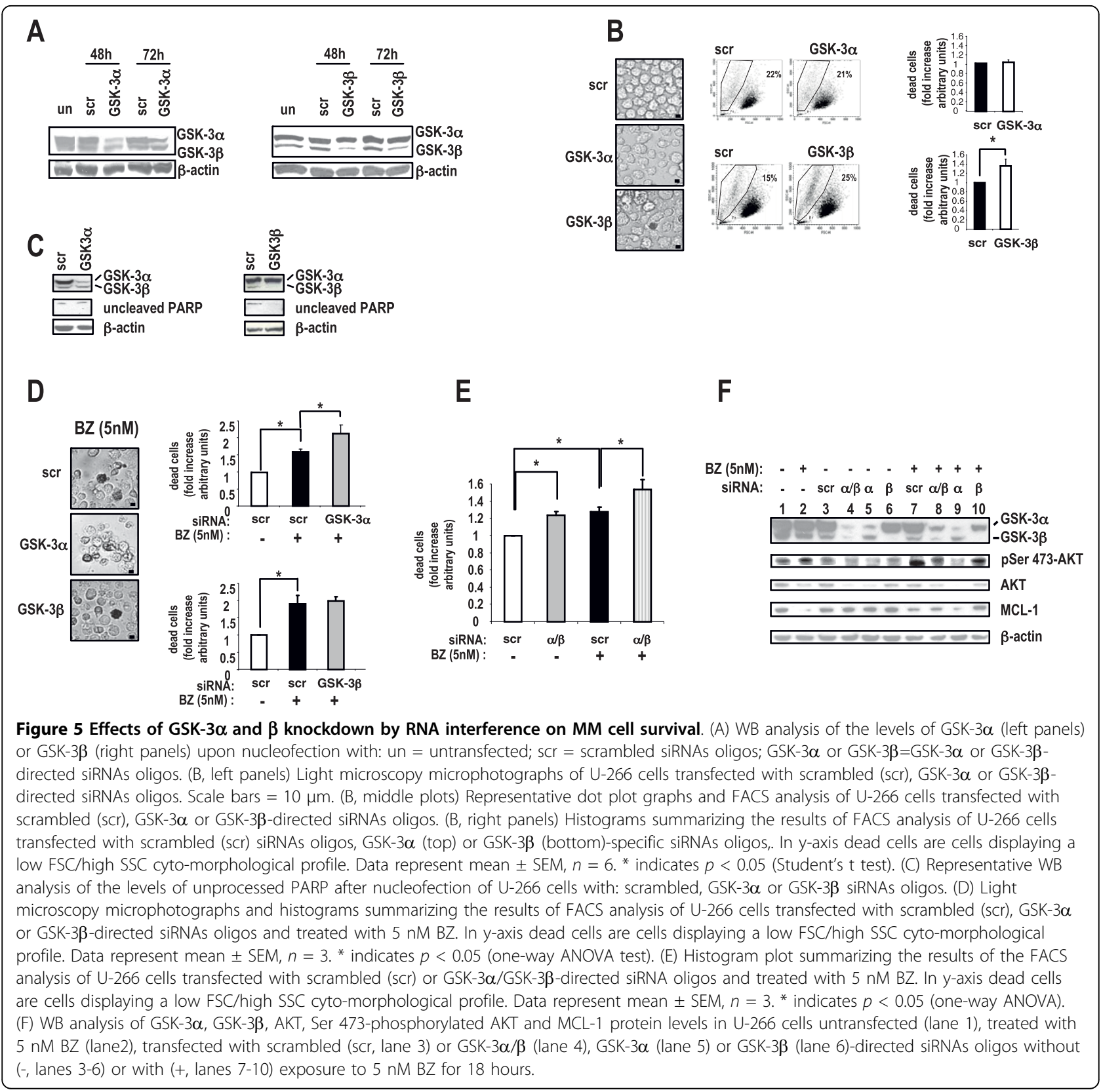

interference-mediated knock down of GSK-3 $\alpha$ and GSK$3 \beta$ expression was associated with decreased MM cell viability $(p<0.05, \mathrm{n}=3)$. Remarkably, silencing of GSK$3 \alpha$ and GSK-3 $\beta$ also augmented the cytotoxic effect of $\mathrm{BZ}(p<0.05, \mathrm{n}=5)$, confirming the results observed with the chemical inhibitors.

\section{AKT and MCL-1 are targets of GSK-3 in MM cells}

We next checked whether silencing of GSK-3 could lead to alterations of BZ-controlled pathways, as observed with the small chemical inhibitors. Immunoblot analysis showed a substantial reduction of GSK-3 $\beta$ or GSK-3 $\alpha$ isoforms in these experiments (Fig. 5F, lanes 4-6, 8-10). $\mathrm{BZ}$ caused a reduction of AKT and MCL-1 protein levels (lane 2). Noteworthy, we observed that in both GSK- $3 \alpha$ and GSK- $3 \alpha / \beta$ double-silenced cells, AKT protein levels were also reduced. As a consequence, silencing of GSK-3 $\alpha$ or GSK-3 $\alpha$ plus GSK-3 $\beta$ was seemingly associated with a slight reduction of phospho-Ser 473 AKT (lanes 4 and 5). This effect was not as obvious in GSK-3 $\beta$-only silenced cells (lane 6). BZ treatment of GSK- $3 \alpha$ and GSK- $3 \alpha / \beta$ double-silenced cells was associated with a marked reduction of AKT protein levels (lanes 8, 9). BZ also caused an increase of phospho-Ser 
473 AKT (lane 2, 7). However, when both or the GSK$3 \alpha$ isoforms were knocked down, this effect was decreased (lanes 8, 9). Intriguingly, it appeared that silencing of GSK-3 $\alpha$ somehow favored whereas silencing of GSK-3 $\beta$ protected against BZ-induced AKT and, even more, MCL-1 degradation (Fig. 5F, lanes 7-10).

\section{Bortezomib induces GSK-3 activation and nuclear translocation}

Since the above results suggest that GSK-3 $\alpha$ can antagonize BZ-dependent cell death and as it has been demonstrated that GSK-3 serine and tyrosine phosphorylation levels and intracellular localization change upon different apoptotic noxae [48], we checked GSK-3 phosphorylation and cellular localization in MM cells upon treatment with BZ. While GSK-3 protein was detectable mostly in the cytosol of untreated cells, it was visible both in the nucleus and in the cytoplasm of cells treated with $5 \mathrm{nM} \mathrm{BZ}$ for 18 hours (Fig. 6A, a graph summarizing the scoring results is shown at the bottom; $p<0.05$, $n=3$ separate experiments). Most interestingly, WB experiments demonstrated a marked reduction of Ser 21/9 GSK-3 phosphorylation, both in the cytosol and in the nucleus, and a slight accumulation of total GSK-3 in the nuclear compartment, upon BZ treatment (Fig. 6B). In all the experiments, BZ was able to induce a significant amount of apoptosis, as assessed by WB analysis of PARP cleavage (Fig. 6B). Since GSK-3 nuclear translocation has been associated with Tyr phosphorylation, which in turn depends on GSK-3 activity itself, we next analyzed by WB the levels of phospho-Tyr GSK-3, total GSK-3 and nuclear/cytoplasm localization upon treatment with two concentrations $(5 \mu \mathrm{M}$ and $10 \mu \mathrm{M})$ of SB216763, 5 nM BZ or both. These experiments (Fig. $6 C)$ revealed that SB216763 efficiently reduced the phospho-Tyr GSK-3 levels in the nucleus and in the cytoplasm; BZ caused a shift of phospho-Tyr GSK-3 and total GSK-3 in the nucleus and, interestingly, treatment with BZ plus SB216763, while it was still associated with a reduction of phospho-Tyr GSK-3, prevented the nuclear shuttling of the kinase.

\section{Discussion}

The involvement of GSK-3 in cancer cell biology has recently been demonstrated. GSK-3 sustains the growth of malignant blood cells, like chronic lymphocytic leukemia (CLL) [34] and acute myeloid leukemia cells (AML) [49]. Our data demonstrated that GSK-3 regulates MM cell growth and survival. Importantly, we also found that GSK-3 modulates MM cell sensitivity to BZinduced apoptosis.

The expression analysis revealed that, in most MM samples from patients and even more, in all the MMCLs, GSK-3 $\beta$ protein levels were lower than GSK-3 $\alpha$. This was not evident in normal controls (PBMC, $\mathrm{nPC}$ ). GSK-3 $\beta$ also resulted more phosphorylated in Ser 9 than GSK-3 $\alpha$ in Ser 21 both in normal and malignant samples; moreover, in the MM samples analyzed for GSK-3 Tyr phosphorylation, we found that GSK-3 $\beta$ was much less Tyr phosphorylated than GSK-3 $\alpha$ (Fig. 1A). Since GSK-3 $\beta$ Ser 9-phosphorylation is associated with a reduction in the enzymatic activity whereas GSK-3 $\beta$ Tyr 216-phosphorylation indicates activation [30], these findings, even if to be validated on a larger number of primary MM samples, indicate that the GSK-3 $\beta$ isoform may be less active than GSK- $3 \alpha$ in normal PBMC and $\mathrm{nPC}$ as well as in MM cells. In these latter cells, however, we observed also a reduction of GSK-3 $\beta$ expression that could contribute to a further down-regulation of its activity. Interestingly, GSK-3 $\alpha$ and GSK-3 $\beta$ do not share the same physiological functions [50]. In particular, GSK$3 \alpha$ does not supply for the loss of GSK-3 $\beta$-dependent NF- $\kappa \mathrm{B}$ regulation in GSK-3 $\beta$ knock out cell, whereas it does in the regulation of the Wnt/ $\beta$-catenin pathway [5]. Our expression studies also showed that in MM plasma cells from patients and some MMCLs (OPM-2, INA-6), GSK-3 was present in the cytosol and partly close to the cell surface, but rarely in the nucleus (Fig. $1 \mathrm{~B}$ and $1 \mathrm{C}$ ). Although in other types of cancer cells GSK-3 localization in the nucleus has been associated to an aggressive behavior, our data indicate that in MM cells at resting conditions GSK-3 nuclear functions might not be selected.

GSK-3 was demonstrated to play an important role in modulating cell growth in several solid tumors and two recent studies have shown that B-CLL and Mixed Lineage Leukemia-associated AML cell survival is greatly impaired by the inhibition of GSK-3 $[34,49]$. Our data indicate that GSK-3 promotes MM cell survival both at basal and under stressed (proteasome inhibition) growing conditions (Fig. 2, 3 and 4). Firstly, the results with the chemical inhibitors SB216763 and SB415286 indicate that GSK-3 inhibition in MM cells leads to a reduction of MM cell growth. This effect is achieved despite the fact that GSK-3 inhibition causes an increase of $\beta$-catenin and phospho-ERK levels, which is expected to result in a growth advantage. Moreover, we have observed that exposing MM cells to GSK-3 inhibitors could augment the response to the cytotoxic effects of $\mathrm{BZ}$, a clinically used chief therapeutic agent in MM therapy. BZ regulates several signaling pathways important for cell survival, among which are the AKT, MCL- $1, \mathrm{NF}-\kappa \mathrm{B}$ and the Wnt/ $\beta$-catenin-regulated cascades [42]. Our results suggest that GSK-3 might positively regulate the AKT and MCL-1-dependent survival pathways which are normally targeted by BZ, since GSK-3 inhibitors cause a reduction of the BZ-triggered AKT phosphorylation and MCL-1 degradation. However, even if selective and 


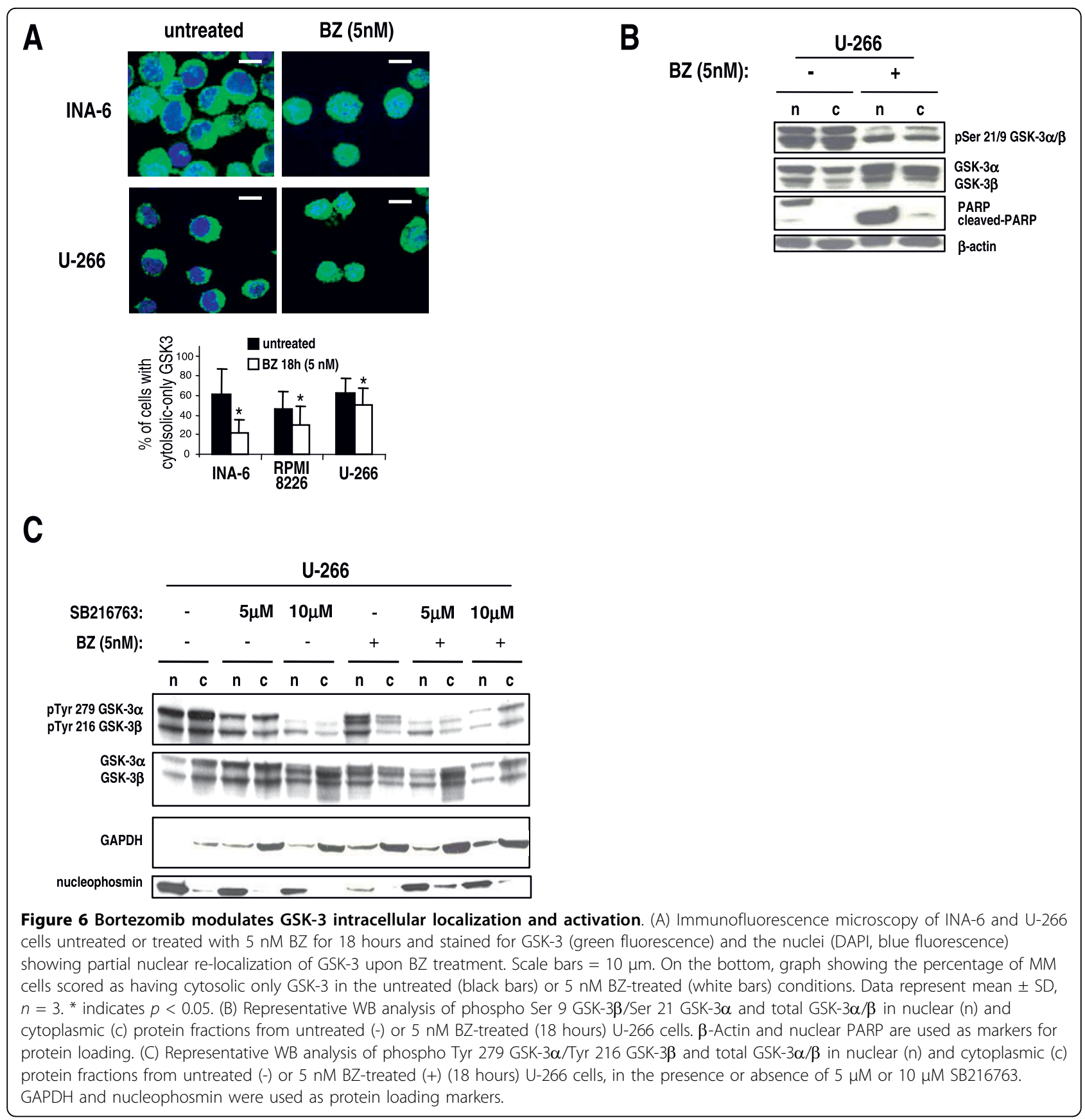

extensively tested, these inhibitors act indistinctly on GSK- $3 \alpha$ and GSK-3 $\beta$, rendering difficult to study isoform-specific functions; additionally, "off-target" GSK-3independent effects could also occur. Nevertheless, GSK- $3 \alpha$ and GSK-3 $\beta$ down modulation by RNA interference in MM cells substantiated the results found with the inhibitors. In fact, our data indicated that GSK-3 $\alpha$ and GSK-3 $\beta$ might control MM cell growth, although in a distinct manner. GSK-3 $\beta$ but not GSK-3 $\alpha$ knock down caused basal MM cell apoptosis whereas GSK-3 $\alpha$ but not GSK-3 $\beta$ knock down was associated with a trend towards increased BZ-induced apoptosis: this would suggest unexpected different roles of the two GSK-3 isoforms in MM cell survival. As mentioned above, the two GSK-3 isoforms can have overlapping functions in regulating the $\mathrm{Wnt} / \beta$-catenin signaling pathway but not other cascades, such as the NF- $\kappa \mathrm{B}$ one, which is mostly dependent on GSK-3 $\beta$ and is critical for MM cell survival $[5,16]$. Even if the analysis of the pretranscriptional steps of the NF- $\kappa \mathrm{B}$ pathway did not 
reveal significative differences upon GSK-3 $\alpha$ or $\beta$ inactivation (data not shown), it is still possible, as already reported by other studies [34], that, even in MM cells, GSK- $3 \beta$ regulates NF- $\kappa$ B transcriptional activity directly on DNA. Moreover, our data suggest that GSK-3 $\alpha$ might control AKT protein turnover, while GSK-3 $\beta$ could modulate MCL-1 protein stability. Clearly, this latter effect of GSK-3 $\beta$ - already described in previous studies [12] - is in contradiction with the evidence that GSK-3 $\beta$ knock down leads to basal MM cell reduced viability. Other signaling pathways should therefore be involved here. In agreement with previous studies, we have shown that BZ induces a reduction of total AKT (with the paradoxical effect of increasing its Ser 473 phosphorylation) and MCL-1 protein levels in MM cells. Interestingly, these BZ-induced biochemical changes were amplified by the treatment with the GSK-3 inhibitors, which were also able to cause a reduction of AKT Ser 473 phosphorylation (Fig. 4). Remarkably, we demonstrated that the siRNA-mediated knock down of GSK3 $\alpha$ and of both the GSK-3 isoforms but not of GSK-3 $\beta$ alone, was associated with the same changes of AKT and MCL-1 levels as seen with the inhibitors. Therefore, our experiments suggest that GSK-3 $\beta$ could influence MM cell survival through MCL-1 and AKTindependent mechanisms, while GSK- $3 \alpha$ could modulate BZ-induced MM cell apoptosis interfering with pathways controlling AKT and MCL-1 protein levels. To note, AKT levels have been demonstrated to be controlled by GSK-3 in previous studies [51].

Furthermore, we provided evidence for a functional link between BZ and GSK-3. Indeed, despite the fact that BZ induces Ser 473 AKT phosphorylation, it caused GSK-3 dephosphorylation in Ser 9/21 and its nuclear migration. However, only a little increase in the GSK-3 Tyr phosphorylation (especially in the nucleus) was seen. It is possible that the BZ-induced modifications are not sufficient to trigger a marked Tyr autophosphorylation; alternatively, a full Tyr autophosphorylation could take place at different time points which were not explored in the current study. To note, these alterations of GSK-3 function have also been demonstrated to occur after cell exposure to other apoptotic noxae and have been related to the pro-apoptotic effects of this kinase [48]. Interestingly, BZ-induced GSK-3 nuclear accumulation seems to depend on GSK-3 activity, since treatment with SB216763 impaired this intracellular shift. However, the exact significance of GSK-3 nuclear migration upon BZ treatment remains to be elucidated. Since GSK-3 inhibition is accompanied by an increased sensitivity to BZ-triggered cell death, it is unlikely that BZ-induced GSK-3 nuclear accumulation triggers a proapoptotic pathway. Oppositely, it is possible that nuclear GSK-3 antagonizes a BZ-dependent nuclear apoptotic pathway. Nonetheless, BZ could trigger GSK-3 activation as a feedback loop to protect MM cells from apoptosis. AKT might be Ser 473 phosphorylated through an unknown, GSK-3-dependent pathway. GSK-3 inhibition would therefore lead to a reduction of phospho-Ser 473 AKT and increased susceptibility to BZ-induced cell death. This unexpected scenario would imply that GSK3 , at basal conditions (to a lesser extent) and in the presence of BZ (to a larger extent), might positively regulate the PI3K/AKT pathway, which in turn is a negative regulator of GSK-3 - as also suggested by the significant amount of GSK-3 (especially GSK-3 $\beta$ ) Ser-phosphorylation found in MM cells (Fig. 1A and 6D). In resting conditions this could represent a regulatory loop whereby GSK-3 might buffer down its own activity. However, upon BZ treatment, being Ser 473 AKT phosphorylation increased, other PI3K/AKT-independent mechanism should take place that justify the reduction of GSK-3 Ser-phosphorylation.

\section{Conclusions}

In conclusion, we have herein demonstrated distinct functions of GSK- $3 \alpha$ and GSK-3 $3 \beta$ in MM cell survival. We have employed two strategies to inhibit GSK-3 $\alpha$ and $\beta$ function: the use of selective chemical compounds, which were already extensively characterized, as well as the more specific RNA interference technology. We have shown that GSK $3 \alpha$ and $\beta$ might promote MM cell survival under different conditions and we have described a link between the action of BZ and GSK-3 providing a mechanistic clue to sustain a viewpoint whereby this cross-talk may occur. Our data could be helpful to improve our knowledge of MM pathogenesis and of the mechanisms of response to novel treatments, as well as to develop novel anti-MM targeted therapies.

\section{Methods}

\section{Patients and cell cultures}

Patients were charged to the University of Padova Hospital. Informed consent was obtained from patients according to the declaration of Helsinki and the laboratory protocol was supervised by the institutional scientific review board at the Department of Clinical and Experimental Medicine, University of Padova. Malignant plasma cells were purified using CD138 -coated microbeads (Miltenyi Biotech, Bergish Gladbach, Germany) according to the manufacturer's protocols. Peripheral blood mononuclear cells (PBMC) and bone marrow (BM) mononuclear cells (BMMC) were obtained from $\mathrm{PB}$ and $\mathrm{BM}$ aspirates of healthy donors and processed as described [52]. Normal plasma cells were generated in vitro as previously described [52]. MM cell lines OPM2 were purchased from the German Collection of Microorganisms and Cell Cultures (DSMZ), RPMI-8226 and 
U-266 were purchased from the American Type Culture Collection (Rockville, USA); the IL-6-dependent MM cell line INA- 6 was a generous gift of Dr. M. Gramatzki, Division of Stem Cell Transplantation and Immunotherapy, University of Kiel, Germany. Cell lines were maintained in RPMI 1640 medium supplemented with 10\% fetal bovine serum, L-glutamine, antibiotics (Gibco Laboratories, Grand Island, NY, USA) under controlledatmosphere in incubators at $37^{\circ} \mathrm{C}$ in the presence of $5 \%$ $\mathrm{CO}_{2}$. Quality controls were made every 8 weeks to check for Mycoplasma contamination, ploidy, immunophenotype and cell morphology.

\section{Chemicals}

GSK-3 $\alpha / \beta$ inhibitors SB216763 and SB415286 were purchased from Sigma-Aldrich, Italy. Bortezomib was purchased from LC laboratories, MA, USA.

\section{GSK-3 activity in cell lysates}

One-2 $\mu$ g of whole cell extracts (WCE) were incubated for $10 \mathrm{~min}$ at $30^{\circ} \mathrm{C}$ with $1 \mathrm{mM} \mathrm{GSK-3 \alpha / \beta}$-specific peptide RRRPASVPPSPSLSRHS(pS)HQRR (Upstate, NY, USA), in the presence of $50 \mathrm{mM}$ Tris- $\mathrm{HCl}, \mathrm{pH} 7.5,12$ $\mathrm{mM} \mathrm{MgCl}_{2}, 10 \mu \mathrm{M}\left[\gamma_{-}{ }^{33} \mathrm{P}\right] \mathrm{ATP}(\sim 3000 \mathrm{cpm} / \mathrm{pmol})$ (Amersham Biosciences, UK), $0.1 \mathrm{M} \mathrm{NaCl}$, in a total volume of $20 \mu \mathrm{l}$. Samples were spotted onto phosphocellulose paper and radioactivity was detected by liquid scintillation as previously described [52].

\section{mRNA silencing}

RNA interference was performed by using small interfering RNAs purchased from Dharmacon, USA. Briefly, U-266 cells $\left(2 \times 10^{6} / \mathrm{ml}\right)$ were nucleofected with the Amaxa ${ }^{\circ}$ system according to the manufacturer's instructions with siGLO green scrambled siRNAs, on-Target plus SMART pool oligos against GSK-3 $\alpha$ and/or GSK- $3 \beta$-targeting siRNAs (100 picomoles). (GSK-3 $\alpha$-specific target sequences: CACAAGCUUUAACUGAGA; GAAGGUGACCACAGUCGUA; GAGUUCAAGUUCCCUCAGA; CUGGACCAACUGCAAUAUUG. GSK-3ß-specific target sequences: GAUCAUUUGGUGUGGUAUA; GCUAGAUCACUGUAACAUA; GUUCCGAAGUUUAGCCUAU; GCACCAGAGUUGAUCUUUG). Cells were immediately put in pre-warmed RPMI complete medium and left in culture for different time lapses. Cells were then harvested and processed to check GSK-3 $\alpha$ and $\beta$ expression by western blot (WB) analysis.

\section{Evaluation of growth and apoptosis}

In $\left[{ }^{3} \mathrm{H}\right]$ thymidine incorporation assay cells were plated in 96 -flat well plates $\left(5 \times 10^{4} /\right.$ well $)$ with different concentrations of GSK-3 inhibitors SB216763 or SB415286. After 48 or 72 hours $\left[{ }^{3} \mathrm{H}\right]$ thymidine was added to the cultures $(10 \mu \mathrm{Ci} /$ well $)$ for the last 12 hours. The $\left[{ }^{3} \mathrm{H}\right]$ thymidine incorporation was evaluated by scintillation counting by using a top count $\beta$-counter (Microbeta Plus; Wallac). For BrdU staining, $2 \times 10^{6} \mathrm{MM}$ cells were incubated with $10 \mu \mathrm{M}$ BrdU in PBS for 30 minutes and afterwards ice-cold PBS was added to stop the incorporation. Samples were centrifuged at $409 \mathrm{~g}$ for $8 \mathrm{~min}$ utes at $4^{\circ} \mathrm{C}$ and pellets were resuspended and fixed in ethanol $70 \%$ in deionized $\mathrm{H}_{2} \mathrm{O}$ for 12 hours. Samples were centrifuged at $409 \mathrm{~g}$ for 8 minutes and left in $2 \mathrm{ml}$ of denaturing solution $(\mathrm{HCl} 2 \mathrm{~N})$ for 10 minutes. Samples were washed, resuspended in Sodium tetraborate $0.1 \mathrm{M}, \mathrm{pH} 8,5$ for 10 minutes, washed and resuspended for 10 minutes in $0.5 \%$ BSA and $0.1 \%$ Tween 20 in PBS. Cells were then incubated for 45 minutes with an antiBrdU primary antibody (Sigma Aldrich, Milan, Italy), washed and incubated for 30 minutes with a FITC-conjugated anti-mouse secondary antibody (BD Pharmingen, Italy). After a wash, $200 \mu \mathrm{l}$ of a solution with 10 $\mathrm{mg} / \mathrm{ml} \mathrm{RNAase}$ and $5 \mu \mathrm{g} / \mathrm{ml}$ di Propidium Iodide was added and samples were analyzed by flow cytometry with FACScalibur and CellQuest ${ }^{\circ}$ analytic software (Becton Dickinson). Apoptosis was assessed by annexin V/ Propidium Iodide staining (BD Pharmingen) or, in separate experiments, by detection of mitochondrial membrane potential [37] using the $5,5^{\prime}, 6,6^{\prime}$, tetrachloro1,1'3,3'-tetraethylbenzimidazolyl carbocyanin iodide dye (JC-1) (Trevigen, Germany) according to the manufacturers' instructions. In the described experiments cell death was evaluated by the analysis of Forward/Side scatter fluorescence changes. Fluorescence Activated Cell Sorting (FACS) analysis was performed using a FACS-Calibur Cell Cytometer and the CellQuest ${ }^{\circ}$ software (Becton-Dickinson, Italy).

\section{Western blot (WB) and antibodies}

Twenty to $40 \mu \mathrm{g}$ of WCE or nuclear and cytoplasmic fractions were subjected to SDS-PAGE and processed by immuno-blot. Detection was performed using chemiluminescence reaction (Pierce, USA). WCE and nuclear and cytoplasmic fractions were prepared according to standard procedures. Antibodies used: GSK- $3 \alpha / \beta$, (Santa-Cruz Biotechnology, CA, USA); GSK- $3 \beta$, $\beta$-catenin, phosphoSer $21 / 9$ GSK-3 $\alpha / \beta$, PARP, MCL-1, ERK1, 2, phosphoThr202/Tyr204 ERK1,2, AKT, phospho-Ser 473 AKT (Cell Signaling Technology, MA, USA); Smac/DIABLO (Upstate/Millipore, USA); phospho-Tyr 279/216 GSK3 $\alpha / \beta$ (Abcam, UK); Nucleophosmin (Invitrogen, CA, USA); GAPDH (Ambion, USA); $\beta$-actin and $\alpha$-tubulin (SigmaAldrich, Italy);

\section{Immunofluorescence and confocal microscopy}

Preparation of cell samples was done as described [52]. For confocal imaging, a Nikon Eclipse TE300 inverted microscope equipped with a PerkinElmer Ultraview LCI 
confocal system was employed; excitation was performed using the appropriate laser lines. Magnification was set at $600 \times$, using an oil immersion objective. Antibodies used were: GSK-3 $\alpha / \beta$, Alexa Fluor ${ }^{\circledR} 488$ goat anti-mouse (Molecular Probes Europe, The Netherlands). To quantify cytosolic and nuclear GSK-3, 200 cells were scored for each different condition and the mean of the percentages of cells with cytosolic only and cytosolic and nuclear GSK-3 was calculated and plotted.

\section{Statistical analysis}

Data obtained were evaluated for their statistical significance with the two-tail paired Student's $t$ test or oneway ANOVA and Bonferroni's correction as post-hoc test for experiments with multiple observations. Values were considered statistically significant at $p$ values below 0.05 .

\section{Acknowledgements \\ This work was supported by grants from the Associazione Italiana Ricerca sul Cancro (AIRC) to GS, the International Myeloma Foundation (to FP). We are indebted to Dr. M. Gramatzki for providing INA-6 cells. We thank all the members of the Hematological Malignancy Unit at the Venetian Institute of Molecular Medicine (VIMM). We are grateful to patients for their availability to donate samples for the study. \\ Author details \\ 'Department of Clinical and Experimental Medicine, Hematology and Clinical Immunology Branch, University of Padua School of Medicine, Via Giustiniani 2 -35128-Padua, Italy. ${ }^{2}$ Venetian Institute of Molecular Medicine, Centro di Eccellenza per la Ricerca Biomedica, Fondazione per la Ricerca Biomedica Avanzata, Via Orus 2 - 35129 - Padua, Italy.}

\section{Authors' contributions}

FP designed and performed the research, analyzed the data and wrote the paper; SM performed the research, analyzed the data, drafted the paper; CG performed the research, analyzed the data; LQT, BM, LP, A Co, M G, AC performed some experiments of the research. FA, RZ and LT contributed patient samples and clinical inputs. GS supervised research, analyzed the data and edited the paper. All the authors read and approved the final manuscript.

\section{Competing interests}

The authors declare that they have no competing interests.

Received: 11 December 2009 Accepted: 4 October 2010

Published: 4 October 2010

\section{References}

1. Woodgett JR: Molecular cloning and expression of glycogen synthase kinase-3/factor A. Embo J 1990, 9:2431-2438.

2. Patel S, Doble B, Woodgett JR: Glycogen synthase kinase-3 in insulin and Wnt signalling: a double-edged sword? Biochem Soc Trans 2004, 32:803-808.

3. Clevers $\mathrm{H}$ : Wnt/beta-catenin signaling in development and disease. Cell 2006, 127:469-480.

4. Reya T, Clevers H: Wnt signalling in stem cells and cancer. Nature 2005, 434:843-850.

5. Hoeflich KP, Luo J, Rubie EA, Tsao MS, Jin O, Woodgett JR: Requirement for glycogen synthase kinase-3beta in cell survival and NF-kappaB activation. Nature 2000, 406:86-90.

6. Liao X, Zhang L, Thrasher JB, Du J, Li B: Glycogen synthase kinase-3beta suppression eliminates tumor necrosis factor-related apoptosis-inducing ligand resistance in prostate cancer. Mol Cancer Ther 2003, 2:1215-1222.
7. Song $L$, Zhou $T$, Jope RS: Lithium facilitates apoptotic signaling induced by activation of the Fas death domain-containing receptor. BMC Neurosci 2004, 5:20.

8. Ougolkov AV, Fernandez-Zapico ME, Savoy DN, Urrutia RA, Billadeau DD: Glycogen synthase kinase-3beta participates in nuclear factor kappaBmediated gene transcription and cell survival in pancreatic cancer cells. Cancer Res 2005, 65:2076-2081.

9. Rottmann S, Wang Y, Nasoff M, Deveraux QL, Quon KC: A TRAIL receptordependent synthetic lethal relationship between MYC activation and GSK3beta/FBW7 loss of function. Proc Natl Acad Sci USA 2005, 102:15195-15200.

10. Hongisto V, Smeds N, Brecht S, Herdegen T, Courtney MJ, Coffey ET: Lithium blocks the c-Jun stress response and protects neurons via its action on glycogen synthase kinase 3. Mol Cell Biol 2003, 23:6027-6036.

11. Linseman DA, Butts BD, Precht TA, Phelps RA, Le SS, Laessig TA, Bouchard RJ, Florez-McClure ML, Heidenreich KA: Glycogen synthase kinase-3beta phosphorylates Bax and promotes its mitochondrial localization during neuronal apoptosis. J Neurosci 2004, 24:9993-10002.

12. Maurer U, Charvet C, Wagman AS, Dejardin E, Green DR: Glycogen synthase kinase-3 regulates mitochondrial outer membrane permeabilization and apoptosis by destabilization of MCL-1. Mol Cell 2006, 21:749-760.

13. Shakoori A, Ougolkov A, Yu ZW, Zhang B, Modarressi MH, Billadeau DD, Mai M, Takahashi Y, Minamoto T: Deregulated GSK3beta activity in colorectal cancer: its association with tumor cell survival and proliferation. Biochem Biophys Res Commun 2005, 334:1365-1373.

14. Ougolkov AV, Fernandez-Zapico ME, Bilim VN, Smyrk TC, Chari ST, Billadeau DD: Aberrant nuclear accumulation of glycogen synthase kinase-3beta in human pancreatic cancer: association with kinase activity and tumor dedifferentiation. Clin Cancer Res 2006, 12:5074-5081.

15. Cao Q, Lu X, Feng YJ: Glycogen synthase kinase-3beta positively regulates the proliferation of human ovarian cancer cells. Cell Res 2006, 16:671-677.

16. Beurel E, Jope RS: The paradoxical pro- and anti-apoptotic actions of GSK3 in the intrinsic and extrinsic apoptosis signaling pathways. Prog Neurobiol 2006, 79:173-189.

17. Potter M: Neoplastic development in plasma cells. Immunol Rev 2003, 194:177-195

18. Hideshima T, Chauhan D, Richardson P, Mitsiades C, Mitsiades N, Hayashi T, Munshi N, Dang L, Castro A, Palombella V, Adams J, Anderson KC: NFkappa B as a therapeutic target in multiple myeloma. J Biol Chem 2002, 277:16639-16647.

19. Annunziata CM, Davis RE, Demchenko Y, Bellamy W, Gabrea A, Zhan F, Lenz G, Hanamura I, Wright G, Xiao W, Dave S, Hurt EM, Tan B, Zhao H, Stephens O, Santra M, Williams DR, Dang L, Barlogie B, Shaughnessy JD Jr, Kuehl WM, Staudt LM: Frequent engagement of the classical and alternative NF-kappaB pathways by diverse genetic abnormalities in multiple myeloma. Cancer Cell 2007, 12:115-130.

20. Hideshima T, Chauhan D, Hayashi T, Podar K, Akiyama M, Gupta D, Richardson P, Munshi N, Anderson KC: The biological sequelae of stromal cell-derived factor-1alpha in multiple myeloma. Mol Cancer Ther 2002, 1:539-544

21. Mitsiades CS, Mitsiades N, Poulaki V, Schlossman R, Akiyama M, Chauhan D, Hideshima T, Treon SP, Munshi NC, Richardson PG, Anderson KC: Activation of NF-kappaB and upregulation of intracellular anti-apoptotic proteins via the IGF-1/Akt signaling in human multiple myeloma cells: therapeutic implications. Oncogene 2002, 21:5673-5683.

22. Qiang YW, Kopantzev E, Rudikoff S: Insulinlike growth factor-I signaling in multiple myeloma: downstream elements, functional correlates, and pathway cross-talk. Blood 2002, 99:4138-4146.

23. Mitsiades N, Mitsiades CS, Poulaki V, Chauhan D, Richardson PG, Hideshima T, Munshi N, Treon SP, Anderson KC: Biologic sequelae of nuclear factor-kappaB blockade in multiple myeloma: therapeutic applications. Blood 2002, 99:4079-86.

24. Derksen PW, Tjin E, Meijer HP, Klok MD, MacGillavry HD, van Oers MH, Lokhorst HM, Bloem AC, Clevers H, Nusse R, van der Neut R, Spaargaren M, Pals ST: Illegitimate WNT signaling promotes proliferation of multiple myeloma cells. Proc Natl Acad Sci USA 2004, 101:6122-6127.

25. Hartmann C: A Wnt canon orchestrating osteoblastogenesis. Trends Cell Biol 2006, 16:151-158. 
26. Krishnan V, Bryant HU, Macdougald OA: Regulation of bone mass by Wnt signaling. J Clin Invest 2006, 116:1202-1209.

27. Tian E, Zhan F, Walker R, Rasmussen E, Ma Y, Barlogie B, Shaughnessy JD Jr: The role of the Wnt-signaling antagonist DKK1 in the development of osteolytic lesions in multiple myeloma. N Engl J Med 2003, 349:2483-2494.

28. Gregory CA, Gunn WG, Reyes E, Smolarz AJ, Munoz J, Spees JL, Prockop DJ: How wnt signaling affects bone repair by mesenchymal stem cells from the bone marrow. Ann N Y Acad Sci 2005, 1049:97-106.

29. Gregory CA, Green A, Lee N, Rao A, Gunn W: The promise of canonical Wnt signaling modulators in enhancing bone repair. Drug News Perspect 2006, 19:445-452.

30. Cross DA, Alessi DR, Cohen P, Andjelkovich M, Hemmings BA: Inhibition of glycogen synthase kinase-3 by insulin mediated by protein kinase B. Nature 1995, 378:785-789.

31. Zhang HH, Lipovsky Al, Dibble CC, Sahin M, Manning BD: S6K1 Regulates GSK3 under Conditions of mTOR-Dependent Feedback Inhibition of Akt. Mol Cell 2006, 24:185-197.

32. Eickholt BJ, Walsh FS, Doherty P: An inactive pool of GSK-3 at the leading edge of growth cones is implicated in Semaphorin 3A signaling. J Cell Biol 2002, 157:211-217.

33. Etienne-Manneville S, Hall A: Cdc42 regulates GSK-3beta and adenomatous polyposis coli to control cell polarity. Nature 2003, 421:753-756.

34. Ougolkov AV, Bone ND, Fernandez-Zapico ME, Kay NE, Billadeau DD: Inhibition of glycogen synthase kinase-3 activity leads to epigenetic silencing of nuclear factor kappaB target genes and induction of apoptosis in chronic lymphocytic leukemia B cells. Blood 2007, 110:735-742.

35. Smith DG, Buffet $M$, Fenwick AE, Haigh D, Ife RJ, Saunders M, Slingsby BP, Stacey R, Ward RW: 3-Anilino-4-arylmaleimides: potent and selective inhibitors of glycogen synthase kinase-3 (GSK-3). Bioorg Med Chem Lett 2001, 11:635-639.

36. Martin M, Rehani K, Jope RS, Michalek SM: Toll-like receptor-mediated cytokine production is differentially regulated by glycogen synthase kinase 3. Nat Immunol 2005, 6:777-784.

37. Cossarizza A, Salvioli S: Flow cytometric analysis of mitochondrial membrane potential using JC-1. Curr Protoc Cytom 2001, Chapter 9, Unit 914.

38. Cole A, Frame S, Cohen P: Further evidence that the tyrosine phosphorylation of glycogen synthase kinase-3 (GSK3) in mammalian cells is an autophosphorylation event. Biochem J 2004, 377:249-255.

39. Lochhead PA, Kinstrie R, Sibbet G, Rawjee T, Morrice N, Cleghon V: A chaperone-dependent GSK3beta transitional intermediate mediates activation-loop autophosphorylation. Mol Cell 2006, 24:627-633.

40. Zhai P, Gao S, Holle E, Yu X, Yatani A, Wagner T, Sadoshima J: Glycogen synthase kinase-3alpha reduces cardiac growth and pressure overloadinduced cardiac hypertrophy by inhibition of extracellular signalregulated kinases. J Biol Chem 2007, 282:33181-33191.

41. Rehani K, Wang H, Garcia CA, Kinane DF, Martin M: Toll-like receptormediated production of IL-1Ra is negatively regulated by GSK3 via the MAPK ERK1/2. J Immunol 2009, 182:547-553.

42. Ocio EM, Mateos MV, Maiso P, Pandiella A, San-Miguel JF: New drugs in multiple myeloma: mechanisms of action and phase I/II clinical findings. Lancet Oncol 2008, 9:1157-1165.

43. Hideshima T, Mitsiades C, Tonon G, Richardson PG, Anderson KC: Understanding multiple myeloma pathogenesis in the bone marrow to identify new therapeutic targets. Nat Rev Cancer 2007, 7:585-598

44. Hideshima T, Catley L, Raje N, Chauhan D, Podar K, Mitsiades C, Tai YT, Vallet S, Kiziltepe T, Ocio E, Ikeda H, Okawa Y, Hideshima H, Munshi NC, Yasui $\mathrm{H}$, Richardson PG, Anderson KC: Inhibition of Akt induces significant downregulation of survivin and cytotoxicity in human multiple myeloma cells. Br J Haematol 2007, 138:783-791.

45. Podar K, Gouill SL, Zhang J, Opferman JT, Zorn E, Tai YT, Hideshima T, Amiot M, Chauhan D, Harousseau JL, Anderson KC: A pivotal role for MCl-1 in Bortezomib-induced apoptosis. Oncogene 2008, 27:721-731.

46. Chen KF, Yeh PY, Yeh KH, Lu YS, Huang SY, Cheng AL: Down-regulation of phospho-Akt is a major molecular determinant of bortezomib-induced apoptosis in hepatocellular carcinoma cells. Cancer Res 2008, 68:6698-6707.

47. Chen KF, Yeh PY, Hsu C, Hsu CH, Lu YS, Hsieh HP, Chen PJ, Cheng AL: Bortezomib overcomes tumor necrosis factor-related apoptosis-inducing ligand resistance in hepatocellular carcinoma cells in part through the inhibition of the phosphatidylinositol 3-kinase/Akt pathway. J Biol Chem 2009, 284:11121-11133.

48. Bijur GN, Jope RS: Proapoptotic stimuli induce nuclear accumulation of glycogen synthase kinase-3 beta. J Biol Chem 2001, 276:37436-37442.

49. Wang Z, Smith KS, Murphy M, Piloto O, Somervaille TC, Cleary ML: Glycogen synthase kinase 3 in MLL leukaemia maintenance and targeted therapy. Nature 2008, 455:1205-1209.

50. Force T, Woodgett JR: Unique and overlapping functions of GSK-3 isoforms in cell differentiation and proliferation and cardiovascular development. J Biol Chem 2009, 284:9643-9647.

51. Nemoto T, Kanai T, Yanagita T, Satoh S, Maruta T, Yoshikawa N, Kobayashi H, Wada A: Regulation of Akt mRNA and protein levels by glycogen synthase kinase-3beta in adrenal chromaffin cells: effects of $\mathrm{LiCl}$ and SB216763. Eur J Pharmacol 2008, 586:82-89.

52. Piazza FA, Ruzzene M, Gurrieri C, Montini B, Bonanni L, Chioetto G, Di Maira G, Barbon F, Cabrelle A, Zambello R, Adami F, Trentin L, Pinna LA, Semenzato G: Multiple myeloma cell survival relies on high activity of protein kinase CK2. Blood 2006, 108:1698-1707.

\section{Pre-publication history}

The pre-publication history for this paper can be accessed here: http://www.biomedcentral.com/1471-2407/10/526/prepub

\section{doi:10.1186/1471-2407-10-526}

Cite this article as: Piazza et al:: Glycogen Synthase Kinase-3 regulates multiple myeloma cell growth and bortezomib-induced cell death. BMC Cancer 2010 10:526.

\section{Submit your next manuscript to BioMed Central and take full advantage of:}

- Convenient online submission

- Thorough peer review

- No space constraints or color figure charges

- Immediate publication on acceptance

- Inclusion in PubMed, CAS, Scopus and Google Scholar

- Research which is freely available for redistribution
C BioMed Central 